\title{
AKTIVITAS HEMAGLUTINASI BAKTERI ACINETOBACTER BAUMANNII YANG BERASAL DARI SPESIMEN KLINIK DAN LINGKUNGAN
}

\section{(HEMAGLUTINATION ACTIVITY Of BACTERIUM ACINETOBACTER BAUMANNII ISOLATED FROM CLINICAL SPECIMENS AND ENVIRONMENT)}

\author{
Noorhamdani \\ Laboratorium Mikrobiologi Fakultas Kedokteran Universitas Brawijaya/ RSU Dr Saiful Anwar Malang
}

\begin{abstract}
Acinetobacter baumannii (Acb) is an opportunistic or a nosocomial pathogenic bacterium which attacks immunocompromised host. Colonization and infection often occur while hospitalized and could lead to pneumonia infection, urinary tract infection, meningitis, septicemia, and burn or surgical wound infections. In spite of the steady increase of Acb infection cases, little has been revealed about the Acb infection mechanism. The infection process is initiated by the adhesion of bacteria onto the host's cell, followed by multiplication, colonization and infection. Adhesion onto the host's cell is mediated by the adhesin molecule functioning as the virulence factor. Adhesin is usually found in the form of hemaglutinin protein which is bound to the receptor available at the host's cell surface. Target of research is to know weather the bacterium have hemaglutinin protein, by seeing the ability of agglutination red blood of mice $0.5 \%$. Isolate of Acb coming from clinical specimen consisted of urine 35 isolates, sputum 27 isolates, pus 15 isolates, and blood 1 isolat. Acb which from environment 2 isolates. Result of positive hemaglutination test got from urine $13 / 35$ (37.14\%), sputum 8 / 27 (29.63\%), pus 5 / 15 (33.33\%) and Acb isolat coming from environment and blood all negativies. This result show Acb isolat of clinical specimen gave positive test has range from $29.63-37.14 \%$ that believed to have protein of hemaglutinin the functioningness as protein of adhesin to attach bacterium at hospes cells. Needed by research continue for the characteristic of the hemaglutinin protein and possibility of hemaglutination test of pathogenic bacterium
\end{abstract}

Keywords: Acinetobacter baumannii, hemaglutination test, hemaglutinin protein.

\section{PENDAHULUAN}

Bakteri Acinetobacter baumannii merupakan patogen opportunistik atau patogen nosokomial, secara alamiah dapat dijumpai di lingkungan, tanah, air dan kotoran (1), bahkan terdapat di mukosa farings dan kulit yang sehat (2). Infeksi pada manusia umumnya terjadi pada penderita dengan keadaan umum yang jelek (3). Acinetobacter baumannii merupakan patogen nosokomial, dapat terjadi kolonisasi dan infeksi pada penderita yang di rawat di rumah sakit $(4,5,6)$. Infeksi yang terjadi berupa pneumonia $(3,7)$, infeksi pada mata $(8,9)$, infeksi pada luka bakar atau luka bedah, infeksi kulit, infeksi saluran kemih, bakteremia dan septikemia (3).

Di Indonesia, bakteri tersebut juga dapat diisolasi dari berbagai spesimen klinik $(10,11)$, dan tampak ada kecenderungan kasusnya makin meningkat. Dari spesimen urin penderita di RSUD Dr Saiful Anwar Malang pada tahun 1994 dapat diisolasi bakteri Acinetobacter baumannii sebesar 5,49 \% (12), dan tahun 1997 meningkat menjadi 7,13 \% (13). Pada penelitian terakhir terjadi peningkatan yang cukup mengkawatirkan, bakteri Acinetobacter baumannii merupakan penyebab infeksi saluran kemih kedua setelah Escherichia coli, yaitu sebesar 14,68 \% (14). Namun, sampai sekarang belum banyak penelitian yang mengungkap bagaimana mekanisme infeksi oleh bakteri tersebut.

Hasil eksplorasi penelitian pendahuluan menunjukkan bahwa Acinetobacter baumannii yang berasal dari spesimen urin

Jurnal Kedokteran Brawijaya, Vol. XX, No.2, Agustus 2004

Korespondensi: Noorhamdani; Laboratorium Mikrobiologi FK Unibraw /RSU Dr. Saiful Anwar Malang, Jl. Veteran, Malang 65145.

Telp. 0341-580993; Fax.0341-564755 penderita penyakit infeksi saluran kemih yang pernah dilakukan kateterisasi di rumah sakit, mampu mengaglutinasi eritrosit mencit. Bakteri yang mampu mengaglutinasi eritrosit menunjukkan bakteri memiliki protein hemaglutinin. Protein hemaglutinin diyakini dapat memperantarai terjadinya adhesi pada sel hospes karena molekul reseptor pada permukaan eritrosit secara umum dapat mewakili sel-sel hospes didalam tubuh yang lain (15). Hal ini memberikan dugaan bahwa bakteri Acinetobacter baumannii memiliki protein hemaglutinin yang berperan sebagai adhesin.

Hal tersebut di atas mendorong untuk melakukan penelitian yang bertujuan mengetahui gambaran aktivitas hemaglutinasi bakteri Acinetobacter baumannii yang diisolasi dari spesimen klinik dan dari lingkungan terhadap kemampuannya mengaglutinasi eritrosit mencit. Dengan diketahuinya faktor virulensi adhesin dari bakteri Acinetobacter baumannii dapat diungkap mekanisme infeksi oleh bakteri tersebut khususnya molekul protein hemaglutinin yang berfungsi sebagai adhesin.

\section{METODE}

Bahan dan alat. Bahan untuk pewarnaan Gram, Agar MacConkey, lempeng agar darah (BAP, blood agar plate) atau agar coklat, bahan Microbact system, reagen uji katalase dan uji oksidase, darah mencit Balb/c, PBS (Phosphate Buffer Saline), inkubator dan lempeng mikrotiter.

Bakteri. Acinetobacter baumannii diperoleh dari spesimen klinik penderita di RSU Dr. Saiful Anwar Malang. Spesimen yang berasal dari lingkungan berupa air bercampur sedikit tanah yang diambil dari persawahan dipinggir sungai Brantas desa Tlogomas Malang. Perbenihan bakteri menggunakan prosedur yang lazim dilakukan di laboratorium Mikrobiologi FK Unibraw/RSU Dr.Saiful 
Anwar. Identifikasi bakteri menggunakan pewarnaan Gram, pemeriksaan mikroskop, uji oksidase dan katalase, dilanjutkan dengan reagen Microbact system (16). Selanjutnya isolat ditanam pada medium agar coklat di inkubasi pada suhu $42^{\circ} \mathrm{C}$, bakteri Acinetobacter baumannii dapat tumbuh pada suhu tersebut.

Metode uji hemaglutinasi (Uji HA) (17). Sampel berupa sel bakteri utuh Acinetobacter baumannii. Masing-masing sampel direaksikan dengan eritrosit mencit 0,5\%, dilihat titer hemaglutinasinya. Mula-mula eritrosit dicuci $3 x$ dengan PBS $\mathrm{pH}$ 7,4 , kemudian dibuat suspensi $0,5 \%$ dalam PBS. Kedalam setiap sumur dari lempeng mikrotiter dimasukkan $50 \mu$ PBS. Kedalam sumur-1 ditambahkan $50 \mu \mathrm{l}$ sampel, selanjutnya dibuat pengenceran serial kedalam sumur berikutnya, kecuali sumur-12 digunakan sebagai kontrol negatif (tanpa diberi sampel). Kemudian kedalam masing-masing sumur ditambahkan $50 \mu \mathrm{l}$ suspensi eritrosit, digoyang selama 5 menit kemudian didiamkan suhu kamar $\left(27^{\circ} \mathrm{C}\right)$ sampai terlihat hasilnya. Hasil uji hemaglutinasi untuk sampel dibaca apabila pada sumur kontrol negatif sudah terlihat hasilnya yaitu gambaran bentuk noda merah seperti kancing baju pada dasar sumur.

\section{HASIL PENELITIAN}

Spesimen diambil dari berbagai macam spesimen klinik (urin, sputum, pus, darah) dan lingkungan. Hasil identifikasi dari bakteri Acinetobacter baumannii dengan pemeriksaan mikroskopis tampak bakteri bentuk batang atau kokobasil Gram negatif, tumbuh baik pada medium agar MacConkey inkubasi $37^{\circ} \mathrm{C}$, koloni bulat, permukaan meninggi, licin, putih buram. Pada medium agar coklat bakteri dapat tumbuh baik pada suhu $42^{\circ} \mathrm{C}$ dan pada lempeng agar darah tidak tampak hemolisis. Uji oksidase negatif, katalase positif, motilitas negatif dan nitrat negatif. Dengan microbact system (identifikasi final 99,99\%): lysine (+), Ornithin (-), $\mathrm{H}_{2} \mathrm{~S}(-)$, Glukose (+), Mannitol (-), Xylose $(+)$, ONPG (-), Indole (-), Urease (-), VP (-), Citrat (+) dan TDA (-). Hasil isolasi didapatkan isolat Acb dari urin 35, sputum 27, pus 15, darah 1 dan dari lingkungan 2 isolat. Pada penelitian ini tidak dijumpai isolat bakteri Acinetobacter baumannii yang berasal dari spesimen liquor, feses, usapan tenggorok dan cairan dari rongga tubuh seperti peritoneum, pleura dan ascites. Hasil uji hemaglutinasi ditampilkan seperti pada Gambar 1 dan Tabel 1.

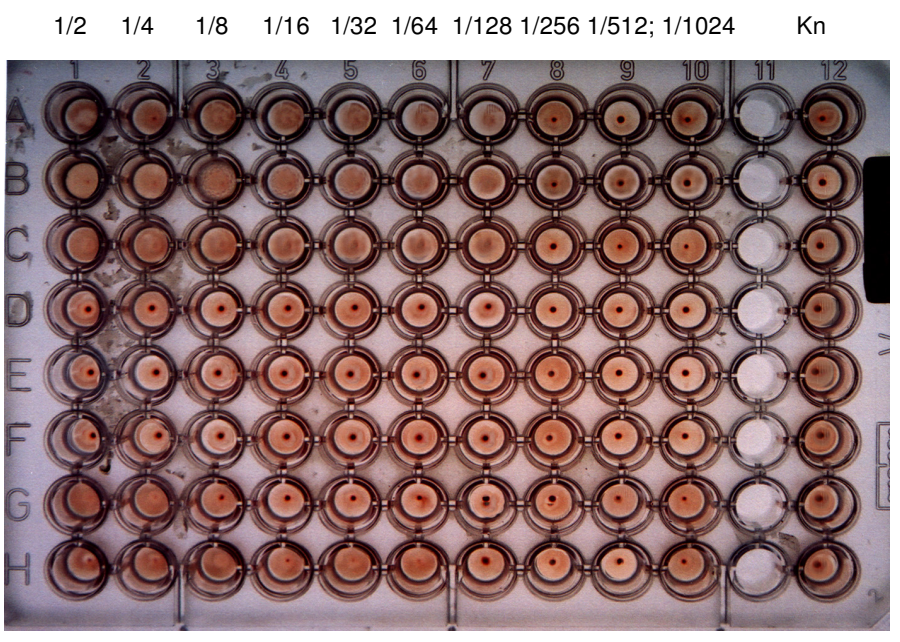

Gambar 1. Hasil Uji Hemaglutinasi menggunakan eritrosit mencit 0,5\% terhadap berbagai galur bakteri Acinetobacter baumannii (Acb) yang berasal dari spesimen klinik dan lingkungan.

\section{Keterangan:}

Angka 1/2 - 1/1024: menunjukkan besar titer (pengenceran) sampel (berisi sampel, PBS dan eritrosit). Kn: kontrol reaksi negatif, berisi eritrosit dan PBS, tanpa sampel, tidak terjadi penggumpalan eritrosit (tampak gambar bentukan noda merah seperti kancing baju pada dasar sumur). Pada baris A, sampel isolat klinik Acb193 (urin, HA positif titer 1/128); B, isolat klinik Acb1508 (sputum, HA positif titer 1/128); C, isolat klinik Acb2797(pus, HA positif titer 1/128); D, isolat klinik Acb325 (urin, HA negatif); $E$, isolat lingkungan, AcbNP (HA negatif); $F$, isolat lingkungan AcbGS (HA negatif); G, isolat klinik Acb446 (pus, HA positif titer 1/4); H, isolat klinik Acb918(sputum, HA positif titer 1/64).

Tabel 1. Hasil Uji Hemaglutinasi terhadap bakteri (sel utuh) Acinetobacter baumannii dari spesimen klinik dan lingkungan

\begin{tabular}{lccc}
\hline \multicolumn{1}{c}{ Asal isolat } & Jumlah isolat & HA Positif $(\%)$ & Kisaran Besar Titer \\
\hline Urin & 35 & $13(37,14)$ & $1 / 2-1 / 128$ \\
\hline Sputum & 27 & $8(29,63)$ & $1 / 2-1 / 128$ \\
\hline Pus & 15 & $5(33,33)$ & $1 / 2-1 / 128$ \\
\hline Darah & 1 & $0(0)$ & 0 \\
\hline Lingkungan & 2 & $0(0)$ & 0 \\
\hline
\end{tabular}

Keterangan :

Uji hemaglutinasi menggunakan eritrosit mencit 0,5\%, merupakan upaya penapisan (skrining) awal untuk mendapatkan protein hemaglutinin. HA positif: bakteri (sampel) mampu mengaglutinasi (menggumpalkan) eritrosit. 


\section{DISKUSI}

Nama bakteri Acinetobacter baumannii belum banyak dikenal di literatur Indonesia, lebih dikenal dengan sebutan Acinetobacter anitratus. Bakteri Acinetobacter baumannii termasuk dalam genus Acinetobacter. Bakteri Acinetobacter sebelumnya dikenal dengan nama Mima polymorpha dan Herellea vaginicola. Sedang spesies Acinetobacter baumannii sebelumnya dikenal dengan nama Acinetobacter calcoaceticus var. anitratus, atau lebih sering disebut Acinetobacter anitratus (18). Dengan teknik hibridisasi DNA telah diketahui 21 genomospesies dari bakteri Acinetobacter spp. (19), bakteri Acinetobacter baumannii dikelompokkan dalam genomo-spesies 2

Bakteri Acinetobacter baumannii berbentuk kokobasil atau diplokokus Gram negatif, tidak memiliki flagella, tidak berspora, memiliki fimbria, bersifat aerob, memberikan uji oksidase negatif dan katalase positif. Pada medium agar MacConkey mudah tumbuh dengan baik $(1,3,20)$. Bakteri Acinetobacter spp dapat tumbuh baik pada suhu $25^{\circ} \mathrm{C}-37^{\circ} \mathrm{C}$. Spesies Acinetobacter baumannii dapat pula tumbuh dengan baik pada suhu $42^{\circ} \mathrm{C}$, sedangkan spesies lain pada suhu tersebut pertumbuhannya kurang baik atau tidak dapat tumbuh (3), bahkan bakteri Acinetobacter baumannii dapat tumbuh pada suhu $44^{\circ} \mathrm{C}$ (19). Pada medium agar darah tidak memberikan reaksi hemolisis $(3,19)$. Cara identifikasi menggunakan Mycrobact system dengan identifikasi final $99,99 \%$ (16), ditambah dengan uji yang lain seperti tersebut diatas, diyakini isolat tersebut sebagai bakteri Acinetobacter baumannii.

Isolat bakteri Acinetobacter baumannii yang berasal dari spesimen klinik sejumlah 78 isolat yang terdiri dari urin sebanyak 35 isolat, sputum 27 isolat, pus 15 isolat, dan darah 1 isolat. Pada penelitian ini tidak dijumpai isolat bakteri Acinetobacter baumannii yang berasal dari spesimen liquor, feses, usapan tenggorok dan cairan dari rongga tubuh seperti peritoneum, pleura dan ascites. Sedang yang berasal dari lingkungan didapatkan 2 isolat. Kemudian isolat-isolat tersebut dilakukan uji hemaglutinasi dan hasilnya seperti yang ditampilkan pada Gambar 1 dan Tabel 1. Hasil uji hemaglutinasi menunjukkan sekitar 26 dari 78 isolat klinik $(29,63 \%$ - 37,14\%) memberikan reaksi hemaglutinasi positif. Sedang 2 isolat bakteri Acinetobacter baumannii yang berasal dari lingkungan keduanya memberikan hasil reaksi negatif. Diyakini isolat Acinetobacter baumannii yang berasal dari klinik yang memberikan reaksi hemaglutinasi positif memiliki protein hemaglutinin. Protein hemaglutinin dianggap sebagai salah satu faktor virulensi dari bakteri patogen $(21,22)$. Berdasarkan anggapan bahwa bakteri yang mampu mengaglutinasi eritrosit memiliki kemampuan melakukan adhesi pada sel mukosa hospes karena reseptor pada membran eritrosit diyakini memiliki kemiripan dengan reseptor pada sel mukosa hospes $(23,24,25)$, maka isolat bakteri Acinetobacter baumannii yang memiliki protein hemaglutinin diyakini mampu melakukan adhesi pada sel hospes adalah galur patogenik.

Adhesin merupakan salah satu faktor virulensi bakteri dan diperankan oleh fimbria (pili) atau protein membran luar (outer membrane protein, OMP) yang dikenal pula sebagai protein Afimbria $(26,27)$. Kemampuan bakteri melakukan adhesi dapat diperantarai oleh protein adhesin $(26,27,28,29)$. Pada beberapa bakteri, misal Salmonella typhi (28), Vibrio cholerae (29), dan Bordetella pertussis (30) memiliki protein hemaglutinin yang berperan pula sebagai adhesin dan bersifat antigenik. Sebaliknya protein adhesin yang diisolasi dari bakteri Vibrio parahaemolyticus (25), Helicobacter pylori (31) dan Klebsiella pneumoniae (32) mampu mengaglutinasi eritrosit. Dengan demikian dapat dikatakan bahwa isolat bakteri Acinetobacter baumannii yang memiliki protein hemaglutinin diyakini mampu melakukan adhesi pada sel hospes adalah galur patogenik dan karena infeksi yang terjadi didapatkan di rumah sakit dapat disebut pula sebagai patogen nosokomial. Isolat-isolat yang memberikan reaksi hemaglutinasi negatif diyakini tidak memiliki protein hemaglutinin adhesin dan nonpatogenik. Walaupun masih perlu dilakukan penelitian lanjut, uji HA dapat diusulkan sebagai tahap awal penapisan menentukan apakah isolat patogenik atau nonpatogenik. Untuk menentukan apakah protein hemaglutinin tersebut bersifat adhesin, dilakukan ekstraksi dan purifikasi protein tersebut baik dari fimbria atau OMP kemudian dilakukan uji adhesi pada sel hospes $(28,29)$.

Dari 26 isolat Acinetobacter baumannii dengan HA positif didapatkan 2 isolat tercampur bersama bakteri batang Gram positif (Bacillus spp.) yaitu 1 isolat Acinetobacter baumannii dari sputum dan 1 isolat dari pus, masing-masing dengan titer $\mathrm{HA}$ sebesar 1/128. Mengingat kedua isolat Acinetobacter baumannii tersebut memiliki titer HA relatif tinggi, tidak tertutup kemungkinan dugaan terjadinya infeksi mikrobial ganda (polymicrobial infection) antara kedua isolat Acinetobacter baumannii tersebut dengan bakteri Bacillus sp. dapat meningkatkan virulensi dari bakteri, untuk itu diperlukan penelitian lanjut.

\section{KESIMPULAN DAN SARAN}

Telah dilakukan penelitian terhadap bakteri Acinetobacter baumannii, khususnya aktivitas bakteri mengaglutinasi eritrosit mencit. Identifikasi bakteri berdasar pemeriksaan mikroskopis, menggunakan media dari Mycrobact system (identifikasi final 99,99\%) agar MacConkey, media agar darah (inkubasi $37^{\circ} \mathrm{C}$ ) didukung uji katalase, oksidase dan pembiakan pada agar coklat (inkubasi suhu $42^{\circ} \mathrm{C}$ ) dapat diisolasi Acinetobacter baumannii dari spesimen urin 35 isolat, sputum 27 isolat, pus 15 isolat, darah 1 isolat dan dari lingkungan 2 isolat.

Dengan uji hemaglutinasi dari 78 isolat klinik yang memberikan hasil reaksi positif sebanyak 26 isolat $(29,63 \%$ $37,14 \%$ ), dan diyakini isolat tersebut galur patogenik. Sedang isolat dari lingkungan sebanyak 2 isolat memberikan hasil reaksi negatif mungkin tidak memiliki protein hemaglutinin dan bukan galur patogenik.

Diusulkan untuk dilakukan penelitian lanjut kemungkinan uji hemaglutinasi disamping sebagai uji penapisan dapat pula sebagai uji virulensi dan menentukan karakteristik protein hemaglutinin dari Acinetobacter baumannii. 
108 Jurnal Kedokteran Brawijaya, Vol. XX, No. 2, Agustus 2004

\section{DAFTAR KEPUSTAKAAN}

1. Holt JG, Krieg NR, Sneath PHA, Staley JT, Williams ST. Bergey's Manual of Determinative of Bacteriology, 9th. Baltimor: William \& Wilkins; 1994.

2. Seifert H, Dijkshoorn L, Gerner-Smidt P, Pelzer N, Tjernberg I and Vaneechoutte. Distribution of Acinetobacter species on Human skin: Comparison of Phenotypic and Genotypic Identification Methods. J Clin Microbiol; 1997; 35: 2819-2825.

3. Holmes B and Howard BJ. Nonfermentative Gram-Negative Bacteria. In: Clinical and Pathogenic Microbiology, $2^{\text {nd }}$ ed. Howard BJ et al (ed.), St Louis, Washington DC, Toronto: CV Mosby Co; 1994: 337-364.

4. Gould IM, MacKenzie F, Thomson C. Acinetobacter Infections, Intensive Care Units, and Handwashing (letter; comment). Lancet, 1995; 345: 122.

5. Humpreys H, Towner KJ, Crowe M, Webster C, Winter R. Acinetobacter Infections, Intensive Care Units, Handwashing (letter). Lancet 1995; 345: 121.

6. Scerpella EG, Wanger AR, Armitige L, Anderlini P, Ericsson CD. Nosocomial Outbreak Caused by a Multiresistent Clone of: Results of Case Control and Molecular Epidemiologic Investigations. Infect Control Hosp Epidemiol, 1995; 16: 92-97.

7. Bilgic H, Akin ES, Tasan Y, Ekiz K, Seber O,. A case of Acinetobacter calcoaceticus Pneumonia. Thorax, 1995; 50: 315-316.

8. Khater TT, Jones DB, Wilhelmus KR. Infectious Crystalline Keratopathy Caused by Gram-Negative Bacteria. American J Ophthalmology, 1997; 124: 19-23.

9. Kirwan JF, Potamitis T, el-Kasaby H, Hope-Ross Mw, Sutton GA. Microbial Keratitis in Intensive Care. B Med J, 1997; 314: 433534.

10. Josodiwondo S. Perbandingan Pola Kepekaan Kuman Isolat Urin Asal Rumah Sakit dan Non-Rumah Sakit Pada Triwulan I Tahun 1994. Jurnal PAMKI, Desember 1994; 7 (1): 7-13.

11. Dzen SM. Multiresisten Acinetobacter anitratus yang di Isolasi dari Bahan Pemeriksaan Klinik. Jurnal PAMKI 1996; 7: 2.

12. Noorhamdani. Pola Kuman Isolat Biakan Urin dan Pola Resistensinya Terhadap Antibiotika di RSUD Dr Saiful Anwar Malang. Maj Kedok Unibraw 1995; 11: 43-52.

13. Noorhamdani. Isolat Acinetobacter baumannii dari Biakan Urin dan Tes Kepekaannya Terhadap beberapa Antibiotik. Maj Kedok Unibraw, 2001, 17:55-58

14. Kasminem. Pola Kuman Isolat Penyebab Infeksi Saluran Kemih dan Pola Resistensinya Terhadap Antibiotika di RSUD Dr Saiful Anwar Malang. Karya Tulis Sebagai Tugas Akhir, Depkes RI, Politeknik Kesehatan Surabaya Jurusan Analis Kesehatan, 2002.

15. Hanne LL and Finkelstein RA. Characterization and Distribution of the Hemaglutinins Produced by Vibrio cholerae. Infect Immun, 1982; 36: 209-214.

16. Microbact System 24E for the Identification of Miscellaneous Gram Negative Bacilli, (tanpa tahun). 3-rd ed. Adelaide, South Australia: Disposible Products Pty.Ltd.

17. McGarey DJ and Allred DR. Characterization of Hemaglutinating Components on the Anaplasma marginale. Initial Body Surface and Identification of Possible Adhesins. Infect Immun, 1994; 62: 4587-4593.

18. Brooks GF, Butel JS, and Morse SA. Jawetz, Melnick and Adelberg's Medical Microbiology, $21^{\text {th }}$ ed. Stamford, Connecticut: Appleton \& Lange, 1998.

19. Schreckenberger PC and von Graevenitz A. Acinetobacter, Achromobacter, Alcaligenes, Moraxella, Methylobacterium, and other Nonfermentative Gram-Negative Rods. In: Manual of Clinical Micrbiology, Murray PR, Baron EJ, Pfaller MA, Tenover FC, Yolken RH (eds.). Washington DC: ASM Press; 1999: 539-543.

20. Buchanan RE, Gibbons NE, Cowan ST, Holt JG, Liston J, Murray RGE, Niven CF, Ravin AW, Stanier RY. Bergey's Manual of Determinative Bacteriology, $8^{\text {th }}$ ed. Baltimore: William \& Wilkins; 1974.

21. Progulske-Fox A, Tumwasorn $\mathrm{S}$ and Holt $\mathrm{S}$. The Expression and Function of a Bacteroides gingivalis Hemaglutinin gene in Escherichia coli. Oral Microbiol Immunol; 1989; 4: 121-131.

22. Hechemy KE, Samsonoff WA, Harris HL and McKee M. Adherence and Entry of Borrelia burgdoferi in Vero cells. J Med Microbiol, 1992; 36: 229-238.

23. Chmiela M, Ringner M and Wadstrom T. Detection of Cell Surface Haemaglutinins of Helicobacter pylori. In: Helicobacter pylori: Techniques for Clinical Diagnosis and Basic Research. Lee A, and Megraud F, (eds.). London, Philadelphia, Toronto, Sidney, Tokyo: WB Saunders Co; 1996: 213-223.

24. Alam M, Miyoshi S, Tomochika K, Shinoda S. Vibrio mimicus Attaches to The Intestinal Mucosa by Outer Membran Hemaglutinin Specific to Polypeptide Moities of Glycoprotein. Infect Immun, 1997; 65: 3662-3665.

25. Nagayama K, Oguchi T, Arita M, Honda T. Purification and Characterizations of a Cell-Associated Hemaglutinin of Vibrio parahaemolyticus. Infect Immun, 1995; 63: 1987-1992.

26. Salyers AA and Whitt DD. Bacterial Pathogenesis A Molecular Approach. Washington DC: ASM Press; 1994.

27. Salyers AA and Whitt DD. Bacterial Pathogenesis A Molecular Approach. Washington DC: ASM Press; 2002.

28. Santoso S. Protein Adhesin Salmonella typhi Sebagai Faktor Virulensi Berpotensi Imunogenik Terhadap Produksi S-lgA Protektif. [Disertasi]. Surabaya: Program Pasca Sarjana Universitas Airlangga. 2002.

29. Sumarno. Karakterisasi Molekuler Protein Adesi Vibrio cholerae 01 M094V dan Protein Reseptornya pada Sel Epitel Usus Halus Tikus Putih (Wistar). Studi Patogenesis Vibrio cholerae 01 M094V. [Disertasi]. Surabaya: Program Pasca Sarjana Universitas Airlangga., 2000. 
30. Kimura A, Mountzouros KT, Relman DA, Falkow S, Cowell JL. Bordetella pertussis Filamentous Hemaglutinin: Evaluation as a Protective Antigen and Colonization Factor in a Mouse Respiratory Infection Model. Infect Immun, 1990; 58:7-16.

31. Evans DG, Evans DJ, Moulds JJ, Graham DY. N-Acetylneuraminyllactose- Binding Fibrillar Hemagglutinin of Campylobacter pylori : a Putative Colonization Factor Antigen. Infect Immun, 1988; 56: 2896-2906.

32. Martino PD, Bertin Y, Girardeau JP, Livrelli V, Joly B, Darfeuille-Michaud A. Molecular Characterization and Adhesive Properties of CF29K, an Adhesin of Klebsiella pneumoniae Strain Involved in Nosocomial Infection. Infect Immun, 1995; 63: 4336-4344. 